\title{
Dimension stones of the North Hungarian masonry arch bridges
}

\author{
Gyula Bögöly**, Ákos Török, Péter Görög \\ Department of Engineering Geology and Geotechnics, Budapest University of Technology and \\ Economics, Budapest, Hungary
}

Received: January 19, 2015; accepted: March 12, 2015

\begin{abstract}
Stone masonry arch bridges in North Hungary represent cultural heritage values. For the maintenance and preservation of these bridges detailed mapping of lithologies and weathering forms are required. The purpose of this paper is to present the identified lithotypes, their conditions (weathering grade) and their petrophysical properties by using in situ lithological mapping, documentation of weathering forms, non-destructive tests and laboratory analyses. Furthermore these analyses demonstrate the difficulties of characterization and diagnostics of the historical construction materials. Additionally the results of condition assessments and the properties of the four different dimension stones from four different sites provide examples for the large dissimilarities regarding the strength parameters. The above-listed parameters are required as input data for stability calculations and modeling of these structures.
\end{abstract}

Keywords: dimension stone, masonry arch, in situ test, laboratory test, dissimilarities

\footnotetext{
* Corresponding author: Mủegyetem rkp. 3, K185, H-1111 Budapest, Hungary;
}

E-mail: bogoly.gyula@epito.bme.hu 


\section{Introduction}

Maintenance and restoration is a common problem of historical stone structures. There are more than 1,500 stone masonry arch bridges in Hungary, which were mostly built in the $18^{\text {th }}$ and $19^{\text {th }}$ centuries. Unfortunately these kinds of structures receive little attention in Hungary and the condition of most of them has deteriorated severely (Gálos and Vásárhelyi 2005). Since traffic, with the related loads, has increased significantly, in many cases the verification of their stability and load-bearing capacity has become necessary. Several research branches deal with the analysis of masonry arches; Gilbert and Melbourne (1994), Giordano et al. (2002), Gubányi-Kléber and Vásárhelyi (2004), Cavicchi and Gambarotta (2006), Orbán (2006), and Callaway et al. (2012) provide some examples. In the past few years several historical stone bridges, mostly in North Hungary, were also investigated by the Department of Building Materials and Engineering Geology. In this paper two bridges from Sóskút, one from Romhány, one form Héhalom and one from Gyöngyöspata are dealt with. As part of these analyses a number of petrophysical properties were measured in situ as well as in the laboratory. The aim of this article is to present the investigated stone materials of these five analyzed masonry bridges; the article will also address the difficulties of the characterization of the strength parameters of such historical structures.

\section{Location and description of studied bridges}

The analyzed bridges are located in North Hungary (Fig. 1). Two of the studied bridges are found in Sóskút village over the Benta Brook. The two-span road bridge in Fig. $2 \mathrm{a}$, which was built at the end of the $18^{\text {th }}$ century, is situated in the central part

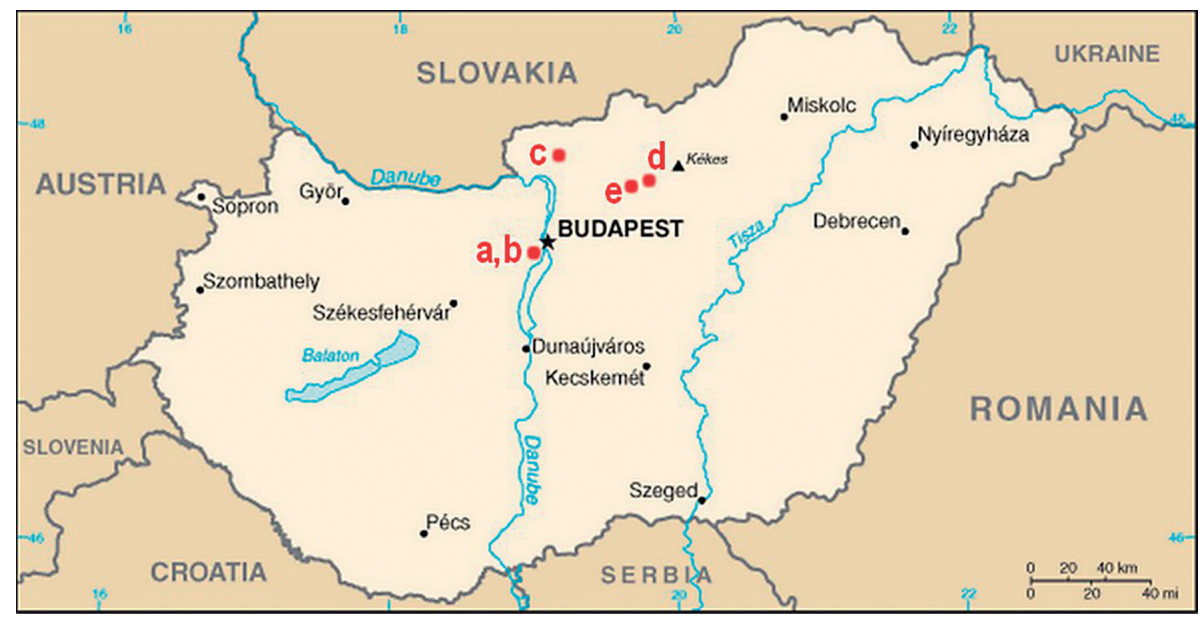

Fig. 1

Locations of the studied bridges in Hungary: a, b) Sóskút, c) Romhány, d) Gyöngyöspata, e) Héhalom 

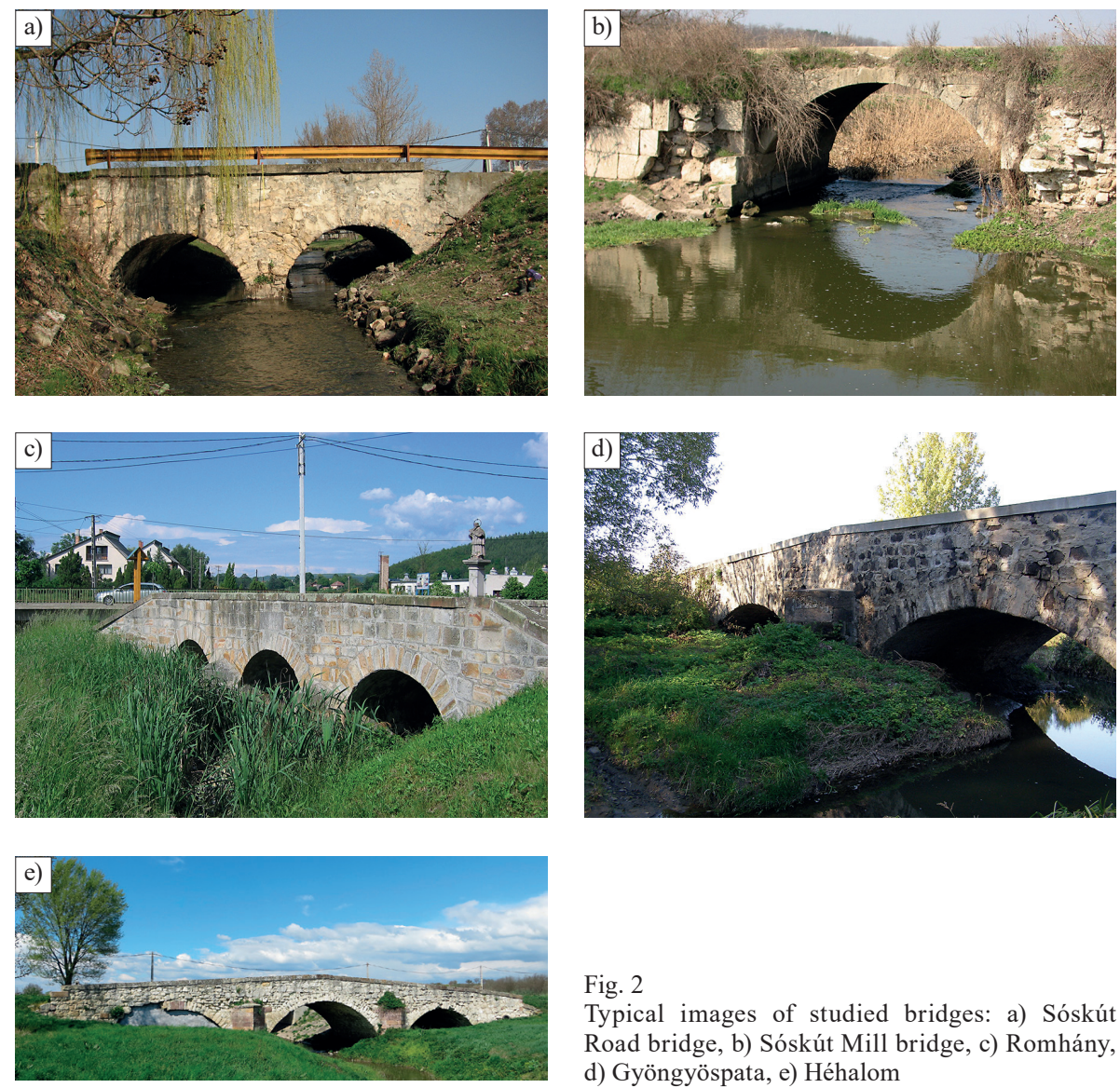

Fig. 2

Typical images of studied bridges: a) Sóskút Road bridge, b) Sóskút Mill bridge, c) Romhány, d) Gyöngyöspata, e) Héhalom

of the village. It has one $3.6 \mathrm{~m}$ and one $3.8 \mathrm{~m}$-long arch, which are separated by a $1 \mathrm{~m}$-wide pier. The full length of the bridge is approximately $9 \mathrm{~m}$. The other bridge (Fig. 2b), known as the Mill Bridge, is close to Kálvária Hill. The partly ruined structure was built more than 300 years ago and is still in use. Its $4.75 \mathrm{~m}$-long arch was made from perfectly fitted blocks without any use of mortar.

A Baroque-style, three-span stone bridge in Romhány over the Lókos Brook, which was built in 1790, was also studied (Fig. 2c). For a few decades the bridge has served pedestrian traffic only. The full length of the structure is $17.8 \mathrm{~m}$. The arches are 2.6, 2.8, and $2.6 \mathrm{~m}$ long. The fourth bridge (Fig. 2d) stands at the southwest border of the village of Gyöngyöspata. The bridge spans the Rédey-Nagy Brook with two $7.5 \mathrm{~m}$-long arches, and serves the road traffic of a busy byroad. The last picture (Fig. 2e) shows the three-span masonry bridge of Héhalom, which is one of our historic monuments. Its construction was finished in 1833. The full length of the bridge is $38 \mathrm{~m}$; its arches over the Bér Brook are 7.4, 9.2, and $7.4 \mathrm{~m}$ long. Since 1975 the structure is not in use. 


\section{Analytical methods}

\section{Identification of the lithotype and the quarry}

The analytical methods of this kind of investigation mostly consist of several steps: collecting historical data on construction as well as in situ and laboratory tests. To obtain historical data is often very difficult. It includes information on historical quarrying and construction activities of the stone structure. In situ analyses can help in the identification of original stone and replaced stones. However, it can be difficult to detect differences between ancient restoration works and original stones, when both of them have been exposed to weathering for a long time. It is also recommended to search for historic quarries and to identify possible sites where the stone was exploited (Přikryl 2007). The accurate identification of the lithotypes is essential in order to plan restoration work. During the restoration either the original stone or replacing material is used. The largest database of dimension stone quarries of Hungary and the Carpathian Basin is found in the work of Schafarzik (1904), who collected and catalogued all of the stone quarries in the territory of historical Hungary. This work provides details regarding the usage of the quarried stone and it also indicates whether the stone was used for bridges or not. Additionally, it is also important to know, for the identification of the stone types, that the smaller bridges were built with local natural stone. The landlords and the owners of the area had the privilege to demand local building materials for free, and most of the quarries belonged to the landowners at that time. Moreover, the construction work and the transportation of stone material also qualified as communal work and were a part of a service owed the feudal lords. These privileges could only be requisitioned by the landlords, which is why the construction activities of stone masonry bridges lasted longer in Hungary than in other parts of Europe. On the other hand it is important to keep in mind that the dimension stones might have come from another quarry which was located farther away; thus it is worthwhile to check the old trade routes (Gáll 1970). These historical details can provide valuable information on the origins of the dimension stones.

\section{In situ tests}

In situ tests included the identification of lithotypes. The distributions of stone types were also recorded in the form of lithological maps showing the positions of the different dimension stones in the stone bridge. Weathering forms were classified according to Fitzner et al. (1995), Török (2002) and ICOMOS (2008). Maps were made presenting the different damage forms (e.g. weathering crust formation, scaling and flaking, fractures, missing blocks, etc.) of the bridges.

The differences in surface hardness of the blocks were measured in situ using a Schmidt hammer. This is particularly suitable technique for the diagnostics of national monument structures to estimate the uniaxial compressive strength (UCS) 
of the rock material when sampling is not an option. During our measurements an N-type Schmidt hammer was used. Moisture has a great influence on the UCS and on the rebound value (Vásárhelyi 2005). Therefore moisture content was also recorded on site.

\section{Laboratory tests}

The petrophysical properties of the different dimension stones were identified under laboratory conditions. Density, strength parameters, and ultrasonic wave velocity were measured according to European Norms (EN).

Rock strength tests were performed on oven-dry and water-saturated cylindrical specimens with a length-to-diameter ratio of 2:1 at ambient temperature. Indirect tensile tests, also known as Brazilian tests, were also carried out on cylindrical specimens, but with a length-to-diameter ratio of 1:1. Unconfined compression and indirect tensile test specimens were $54.1 \mathrm{~mm}$ in diameter.

Additionally, on some samples water saturation and frost resistance tests were carried out. Frost resistance of rocks is defined as their capability to sustain without collapse multiple freezing events alternating with thawing. Frost resistance is estimated by the number of freeze-thaw cycles corresponding to reduction of strength (Yershov 2004). According to the MSZ 1991:1960 Hungarian standard (Table 1) the stones must be qualified by the number of the cycles that the stone material sustained without any damage:

Table 1

Categories of frost resistance (MSZ 1991:1960)

\begin{tabular}{ll}
\hline 15 or less cycles & "Frost dangerous" \\
\hline $16-24$ cycles & "Moderately frost-resistant" \\
\hline $25-34$ cycles & "Frost-resistant" \\
\hline $35-49$ cycles & "Acutely frost-resistant" \\
\hline 50 or more cycles & "Highly frost-resistant" \\
\hline
\end{tabular}

\section{Results}

\section{Identified lithotypes and the quarries}

Porous limestone from the Sóskút area. The two analyzed bridges in Sóskút were built of porous limestone which was exploited from the nearby quarry of Sóskút. This limestone (Fig. 3a) belongs to the Miocene (Sarmatian) Tinnye Limestone Formation. It is light yellow in the quarries, but when exposed to weathering or pollution its 

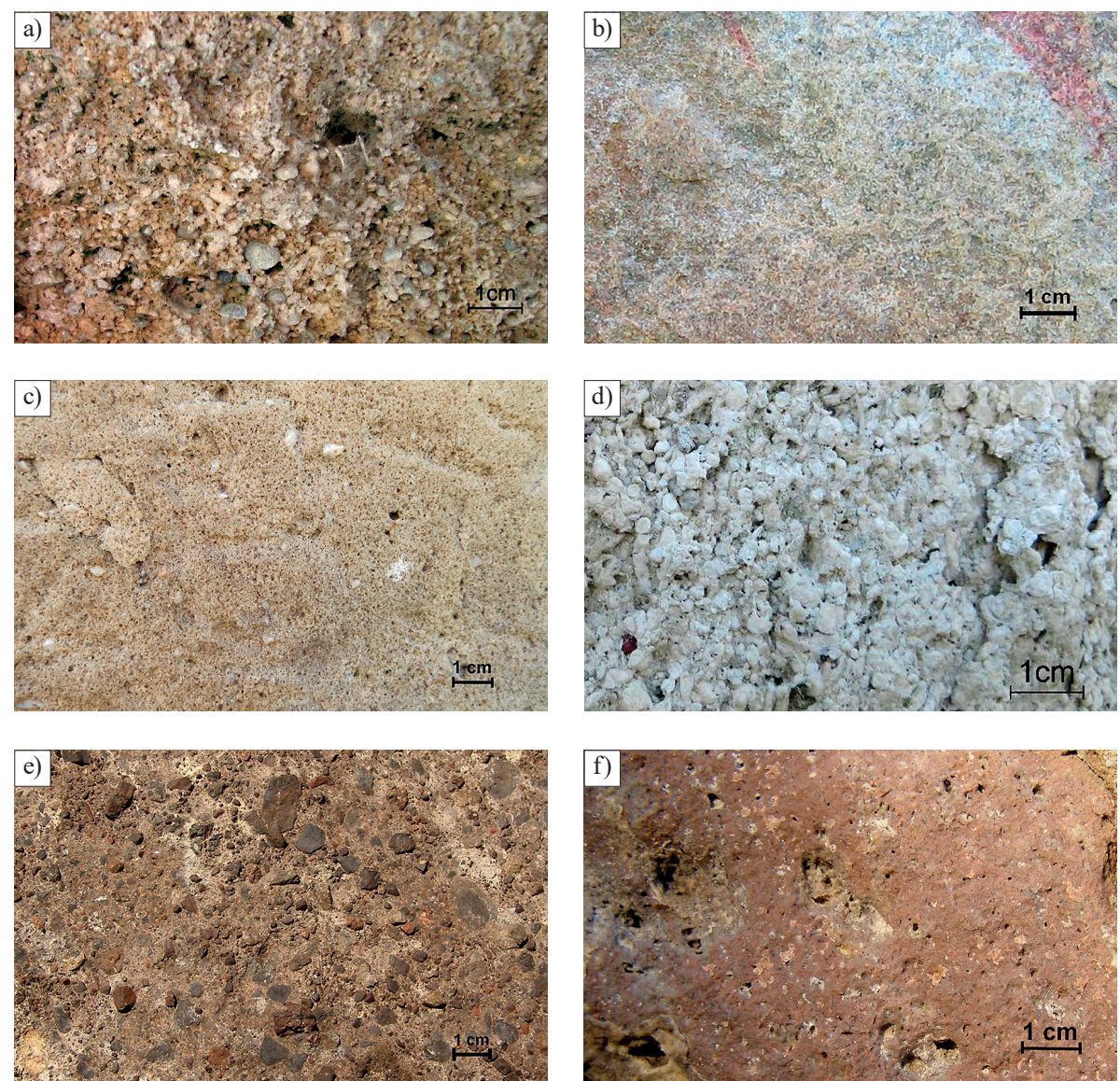

Fig. 3

Identified lithotypes: a) Porous limestone from the Sóskút bridge, b) Sandstone from the Romhány bridge, c) Sandstone from the Héhalom bridge, d) Porous limestone from the Héhalom bridge, e) Andesite tuff from the Gyöngyöspata bridge, f) Rhyolite from the Gyöngyöspata bridge

color changes to white, grey or black. It consists of small, rounded calcitic ooids and micro oncoids of $0.2-2.0 \mathrm{~mm}$ in diameter and bioclasts of the same size. Although calcite $\left(\mathrm{CaCO}_{3}\right)$ is the primary mineral, small quantities of quartz and feldspar are also present. Gypsum $\left(\mathrm{CaSO}_{4} \times 2 \mathrm{H}_{2} \mathrm{O}\right)$ was not detected in the quarry stones (Török 2003). Generally, this limestone has a high porosity; it is light and can be carved easily. Therefore it is a widely-used dimension stone in Hungary; however it is usually frost-sensitive. Characteristic physical properties are presented in Table 2. The limestone shows a great variety of weathering forms. Black crust formation (Fig. 4a) and white crusts are common weathering features. Mechanical weathering appears in the form of scaling and flaking, as well as granular disintegration. Freeze / thaw-induced 

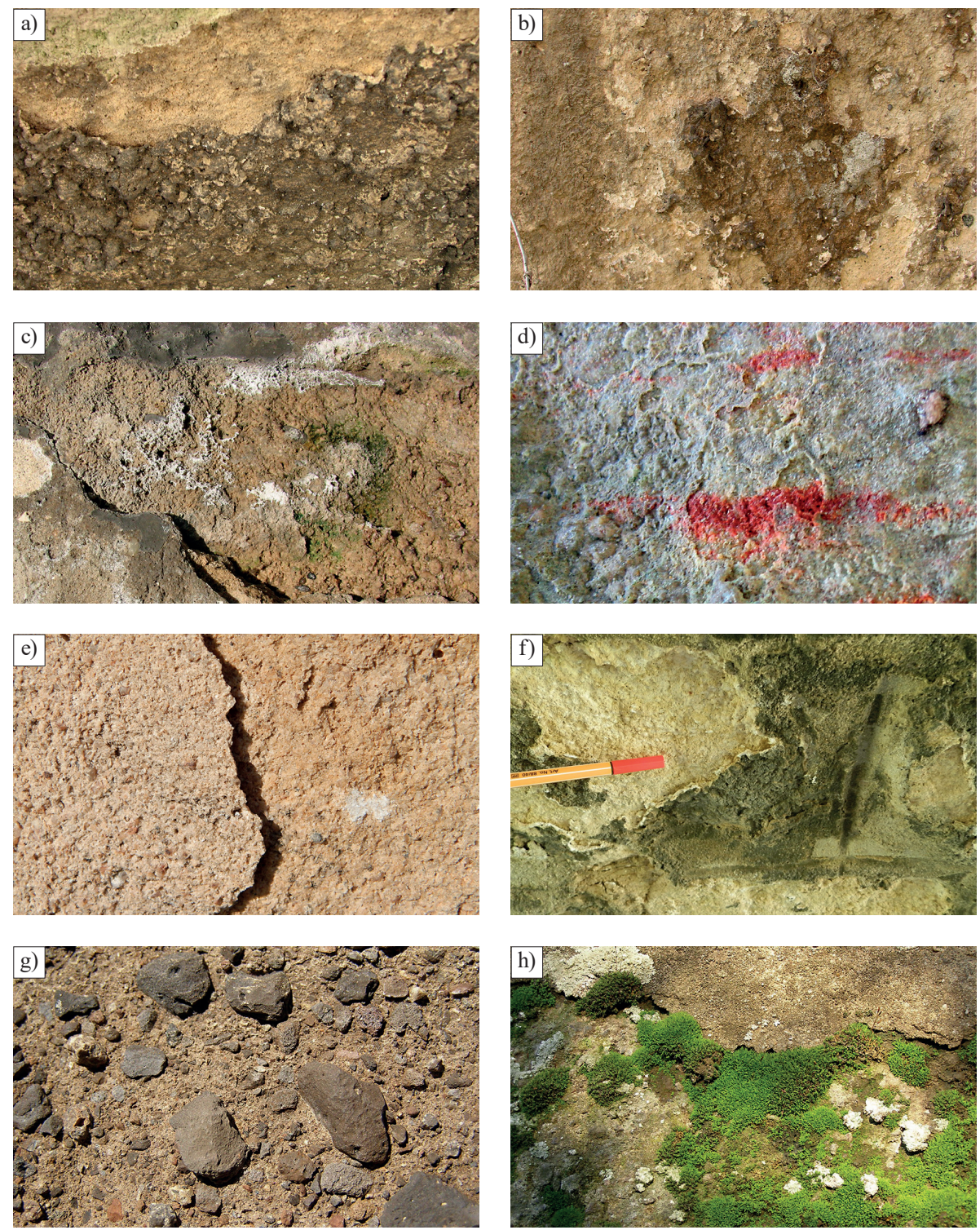

Fig. 4

Weathering forms: a) Black weathering crust on the Sóskút Mill bridge, b) Black crust and blistering on porous limestone, Sóskút Mill bridge, c) Salt efflorescence on the Sóskút Road bridge, d) Blistering on sandstone, Romhány bridge, e) Scaling of the sandstone on the Héhalom bridge, f) Black weathering crust and the removal of the crust by scaling, porous limestone of the Héhalom bridge, g) Selective weathering of the lapilli of the Gyöngyöspata bridge, h) Biological colonization on andesite tuff, Gyöngyöspata bridge 
damage is also common. Blistering is a typical weathering form of porous ooidal limestone (Fig. 4b). Observed salt efflorescence (Fig. 4c) is generally related to improper repair work and the use of Portland cement.

Sandstone from the Romhány quarry and the Pásztó area. The blocks of the Baroque style three-span stone bridge in Romhány were made of fine-grained sandstone from the local quarry. The sandstone belongs to the Hárshegy Sandstone Formation. The quartzarenite was deposited in a shallow marine environment during the Oligocene. Typically it has beige to slightly brownish color (Fig. 3b). Reddish varieties also occur. Both types are characterized by siliceous-limonitic cementation. Since the grain-size and the rate of cementation are variable, the sandstone shows great variety in terms of physical properties (see below).

Sandstone is also one of the building materials of the three-span bridge in Héhalom. The red fine-grained silica-cemented quartz sandstone belongs to the Oligocene Hárshegy Sandstone Formation (Fig. 3c). Besides silica, iron-oxy-hydroxide is also found as pore-filling or in grain envelopes. Small rounded quartz pebbles also form an important part of the microfabric. The main weathering form of sandstone is scaling (Fig. 4e) or flaking. Small-scale micro-cracking also occurs.

Porous limestone from the Nagykökényes-Buják area. The main dimension stone of the national monument bridge in Héhalom is porous limestone. Presumably this stone came from the abandoned nearby quarries of Nagykökényes or Buják, which assumption is also confirmed by the fact that the region of the bridge belonged to the Buják estate in the 19th century (Gubányi-Kléber and Vársárhelyi 2004).The limestone belongs to the Miocene Lajta Limestone Formation. It is a bioclastic grainstone with abundant red algae fragments and with some micro-oncoids (Fig. 3d). The stone is sensitive to weathering. Typical weathering forms are crust formation (Fig. 4f), scaling and flaking. Granular disintegration also occurs in frost-affected zones.

Dimension stones of the Gyöngyöspata region. The bridge located at the edge of Gyöngyöspata was built with different igneous rocks that are typically found in that region and used locally as construction materials. The main dimension stone of the bridge is andesite tuff with larger lapilli (Fig. 3e). Additionally one finds pink vitreous rhyolite with flow structure (Fig 3f), grey rhyolite with vuggy fabric, and dark grey andesite. The main weathering forms are selective weathering of andesite tuff with relief formation (Fig. 4g), micro-cracking or biological colonization (Fig. 4h).

\section{In situ diagnostic tests}

Different lithotypes and damages were recorded on site. As an example, the Héhalom bridge is presented here. At the Héhalom bridge porous limestone predominates (Fig. 3d), while red and yellow sandstone (Fig. 3c) as well as a few blocks of rhyolite tuff were also identified (Fig. 5). Most of the structure, especially the porous limestone, shows very intense weathering (Fig. 4f). Yellow sandstone rarely show weathering features and only minor scaling occurs (Fig. 4e), but red silica-cemented sandstone is almost intact, as is indicated on the detailed damage maps of the bridge 


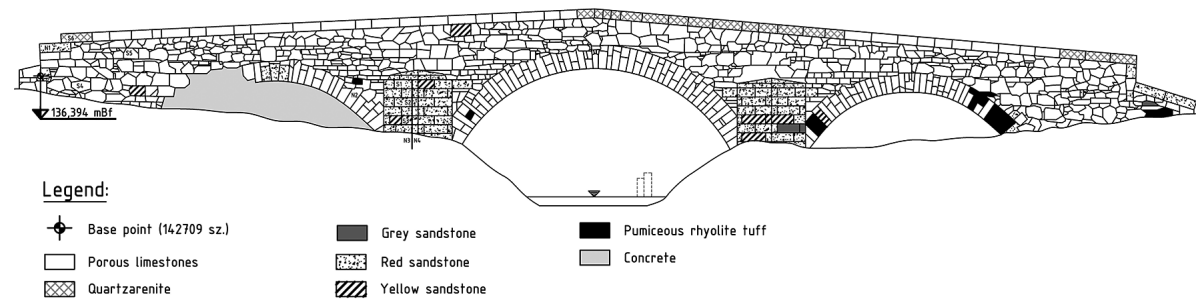

Fig. 5

Stone map of the southeast side of the bridge at Héhalom

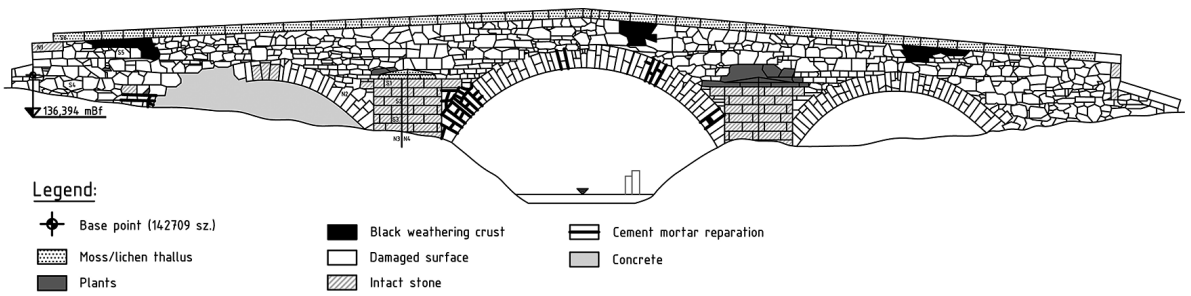

Fig. 6

Damage map of the southeast side of the bridge at Héhalom

(Fig. 6). These maps served as a basis for the documentation of in situ non-destructive tests. This bridge is a unique example where a great variety of stones was used. It also clearly demonstrates that different lithologies have different durability and show different weathering grades, even though they were exposed to the same conditions.

The non-destructive strength test using a Schmidt hammer shows that the rebound values of the dimension stones that were used as construction materials of

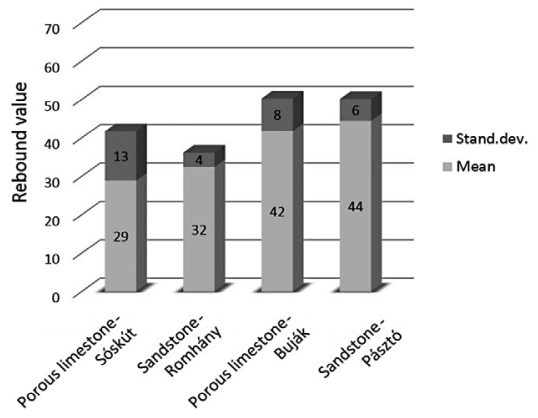

Fig. 7

Schmidt hammer test results of the different stone types

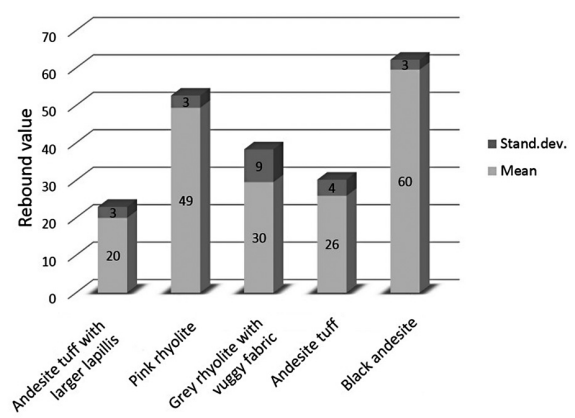

Fig. 8

Schmidt hammer test results of the Gyöngyöspata bridge 
the bridges have significant differences (Fig. 7). It can be observed that the limestone and sandstone of these bridges have overlapping Schmidt hammer values; however, porous limestone has an observably higher standard deviation than sandstone. The coefficient of variation (relative standard deviation) of the rebound values are $44.8 \%$ (Sóskút), 19.0\% (Buják), 13.6\% (Pásztó), 12.5\% (Romhány). The difference between the deviations is due to the diversity of the porous limestone concerning porosity, texture, and fossil content. The presented results do not include rebound values of weathered surfaces; thus weathering does not influence the results.

An example showing rebound values of several different igneous rocks are given in Fig. 8. Furthermore, it demonstrates that the surface hardness of these stones varies significantly. Although there is no linear correlation between the surface hardness and the unconfined compressive strength, these results unequivocally show that the precise estimation of masonry strength is a difficult task.

\section{Laboratory tests}

Laboratory tests were carried out on block samples obtained from the fallen blocks that were found near the bridges (Table 2). The mean values and the standard deviations of the characteristic petrophysical properties show significant differences. It is necessary to note that most of the analyzed structures are protected; thus it was not possible to obtain a statistically adequate number of samples for all tests. Therefore the number of samples is also represented with the results, as a sign of statistical reliability.

The results show that both unconfined compressive strength (UCS) and tensile strength of each stone have a high standard deviation. The coefficient of variation of UCS is considerably higher in the case of the porous limestone (Sóskút: $74.03 \%$ and Buják: 48.62\% versus Pásztó: $32.6 \%$ and Romhány: 15.61\%). The average coefficient of variation of the UCS in case of the two sandstone types is $24.11 \%$, while in case of the two porous limestone type this value is $61.32 \%$. This is a great uncertainty regarding the strength parameters, and it can be larger if even more different dimension stones are concerned. For calculating the load-bearing capacity of stone masonry bridges the compressive strength or the masonry strength is a necessary basic input parameter. Thus it is obvious that the uncertainty of these parameters causes difficulties.

Beside the load-bearing capacity the most important classification viewpoint in the case of the selection of the dimension stones of a masonry arch is the life expectancy, i.e. weathering and frost resistance. Therefore water saturation and frost resistance tests were carried out on some sample. Fig. 9 shows the results of the water saturation of the sandstone from the Pásztó quarry, the porous limestone from the Buják quarry and the Sóskút quarry in this particular order. The water saturation test lasted 2 days in all cases, but in the figures only the relevant time periods are presented. Each curve on the graphs represents a different sample. The total saturation lasted approximately 2 days in case of the sandstone (Fig. 9a); it was approx. 4 hours 


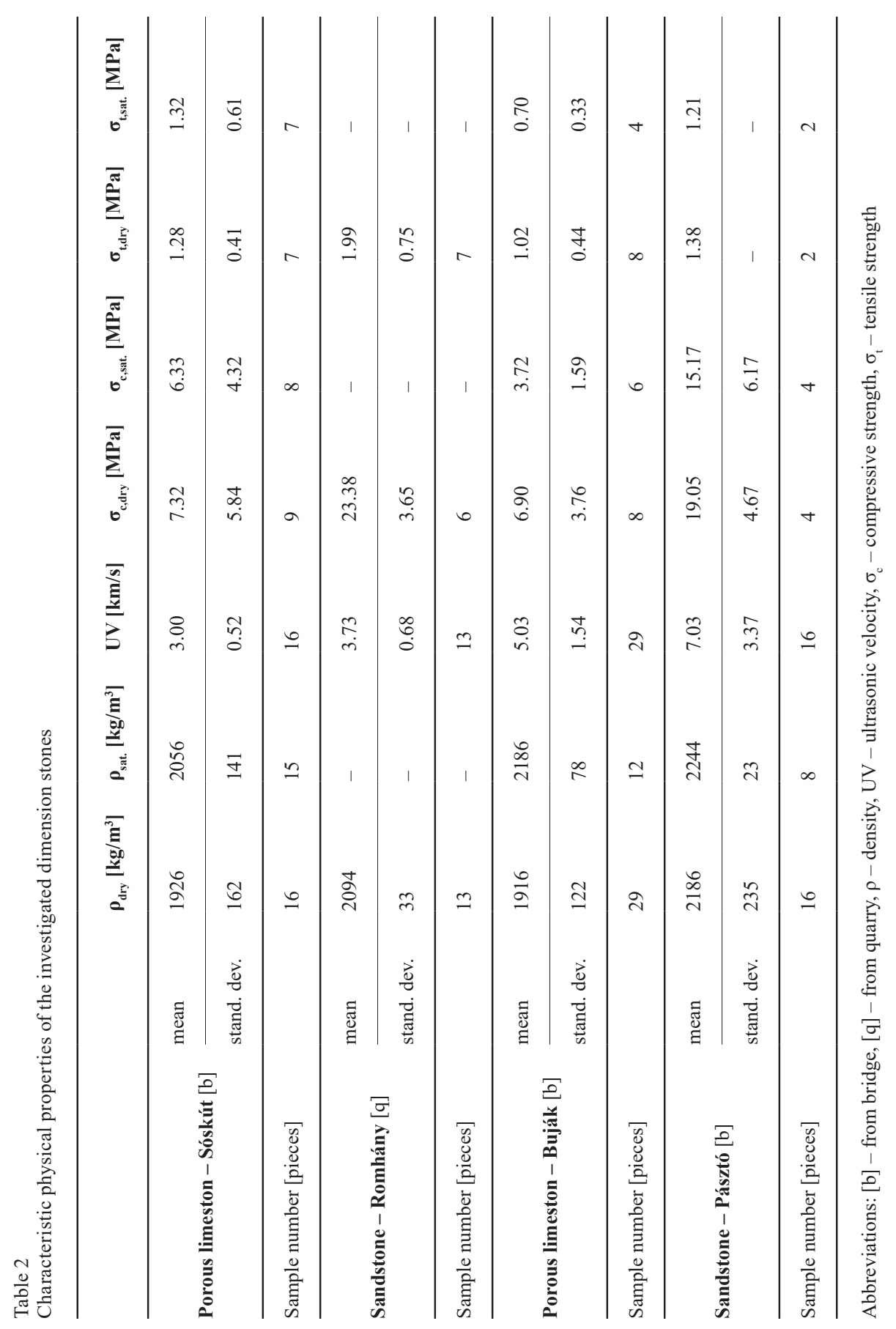



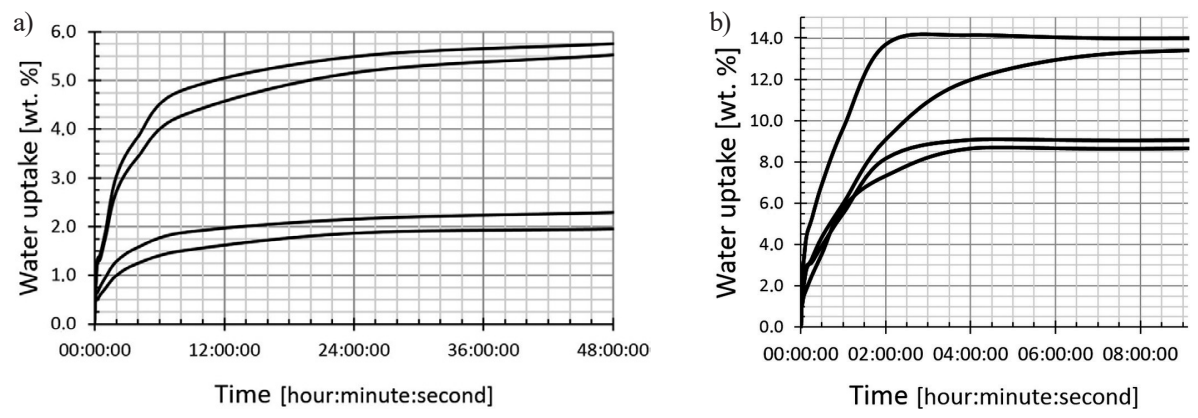

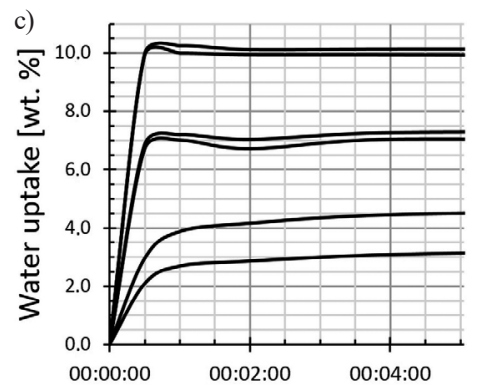

Time [hour:minute:second]
Fig. 9

Water saturation curves of sandstone (a) and porous limestone (b) and (c). Note the differences in horizontal scale and rapid water absorption of porous limestone: a) sandstone samples from the Pásztó area; b) porous limestone samples from the Buják area, c) porous limestone samples from the Sóskút area

in the case of the limestone from Buják (Fig. 9b), and it needed only approx. one hour in the case of the limestone from Sóskút (Fig. 9c). In each sample group there was a significant difference between the separate samples. This is related to the micro-fabric differences of the tested stones, i.e. differences in pore geometries and pore-size distribution.

Frost resistance tests show similar results. Two sandstone samples and three porous limestone samples from Buják were tested. The limestone samples were damaged after 18-20 cycles, while the sandstone samples were not damaged even after 50 freeze-thaw cycles. According to Table 1, the sandstone samples from the Pásztó area can be ranked as highly frost-resistant. The limestone samples from Buják can be categorized as moderately frost-resistant.

\section{Discussions}

The lithological differences are reflected in the intensity of weathering of dimension stones of the studied bridges. The weathering forms of porous limestone of the Sóskút bridges and the Héhalom bridge are very similar to the ones described from other porous limestone monuments of Hungary (Török 2003, 2007; Török et al. 2011), Austria (Bednarik et al. 2014), the Czech Republic (Přikryl et al. 2002; Török et al. 2004) or France (Janvier-Badosa et al. 2014). Black crust formation is related to dust 
deposition even at bridges that are found in rural areas, as was shown in the previous studies (Török et al. 2011). Fine-grained sandstone ashlars show typical weathering features such as scaling and flaking that are very similar to sandstone described from other parts of the World (Turkington and Paradise 2005; Warke et al. 2006). The damage is related to freeze-thaw cycles, or in some cases, to salt-induced or thermal cycles (Smith et al. 2002). Due to the location and environmental factors the sandstones of the studied bridges are mostly affected by freeze-thaw cycles and thermal insolation cycles, rather than salt-induced weathering.

The results of strength tests demonstrated that the studied dimension stones of the analyzed structures show great dissimilarities in terms of uniaxial compressive and tensile strength. The scatter in strength values can be even larger when the structure was built with different lithotypes. These lithological differences are also reflected in petrophysical properties, since data sets show larger scattering when various lithotypes are tested, even from one bridge. It has also been suggested that weathering changes the physical parameters, especially strength. Freeze-thaw damage has a negative effect on compressive strength of limestone (Martínez-Martínez et al. 2013). It has also been demonstrated that weathering can cause an increase in strength when weathering crusts are formed on porous limestone (Török 2003). Beside freeze-thaw damage, salt-related crystallization pressure can also play a key role in the damage of stone masonry structures (Yu and Oguchi 2010).

The in situ diagnostics of strength parameters also requires further considerations. The use of the Schmidt hammer in strength tests (Kahraman 2001; Yilmaz and Sendir 2002; Yasar and Erdogan 2004; Aydin and Basu 2005) and in the diagnostics of stone structures (Török 2003) has been discussed in detail. By using this widespread, non-destructive technique it is possible to estimate the compressive strength of concrete and rock. However, the correlation between the rebound value and the uniaxial compressive strength (UCS) is difficult to establish, since it differs for different lithotypes (Zhang 2005). The rebound value depends on several properties such as: weathering grade, dry density, porosity, grain size, and moisture content. The parameters of the Schmidt hammer (impact energy, plunger tip) also influence the strength (Aydin and Basu 2005). Additionally, there are several contradictory suggestions on which type of the Schmidt hammer is recommended for use. According to the International Society for Rock Mechanics (ISRM 1978) the L-type hammer, which has the lower impact energy, should be used for the hardness characterization for rocks having uniaxial compressive strength (UCS) between 20 and $150 \mathrm{MPa}$. On the other hand some authors suggest that the N-type hammer outperforms the L-type (Buyuksagis and Goktan 2007), because of the higher impact energy. The American Society for Testing and Materials (ASTM 2001) does not prefer a specific hammer type at all. Although both types of Schmidt hammers are capable of testing the surface hardness of rocks, there is no widely used applicable formula or method to estimate the uniaxial compressive strength of stone materials from the rebound value of the Schmidt hammer test. Therefore it can only be used for comparing the condition and the weathering grade of individual stone elements of a structure. 
Masonry arches can resist only minimal tension, and this fact especially influences the behavior of the structure. Stresses are usually low; thus the failure of material is rare in masonry arches (Heyman 1995). Therefore it is necessary to clarify not only the load-bearing capacity but also the life expectancy and durability of the stone, i.e. frost and salt resistance. It is also necessary to emphasize that beside the lithology (Přrikryl and Št'astná 2010) the joints and composition or decay of mortar (Přrikryl et al. 2010) significantly influence the stability of the structure.

\section{Conclusions}

For the construction of the studied bridges, local dimension stones were used, exploited from nearby quarries of each region. The most common lithologies were porous Miocene limestone (Sóskút area and Buják area) and brownish-red Oligocene sandstone of the Hárshegy Sandstone Formation (Romhány, Héhalom). Lithological mapping and mapping of decay form indicate that co-existing lithotypes with the same history of exposure show very different weathering forms and preservation.

In situ non-destructive strength tests, such as with the Schmidt hammer, were applied and test results indicate that rebound values show a significant scatter, even for the same lithologies. Laboratory tests also show that even similar lithotypes have large dissimilarities in terms of their strength parameters. The highest coefficient of variation in terms of unconfined compressive strength and surface hardness was found for the limestone from Sóskút. Less data scatter was found for the limestone from Buják, the sandstone from Pásztó and that from Romhány. With reference to the weathering and frost resistance, sandstone proved to be a more suitable dimension stone for masonry bridges.

\section{Acknowledgements}

We acknowledge the help of several students working in the field and in the laboratory on stone structures, namely Orsolya Tasnádi and Olivér Himmel. During the laboratory testing the technical assistance of Gyula Emszt and Bálint Pálinkás was also appreciated.

\section{References}

ASTM 2001: Standard Test Method for Determination of Rock Hardness by Rebound Hammer Method. - ASTM Stand., 04.09, D 5873-00.

Aydin, A., A. Basu 2005: The Schmidt hammer in rock material characterization. - Engineering Geology, 81, pp. 1-14.

Bednarik, M., B. Moshammer, M. Heinrich, R. Holzer, M. Laho, J. Rabeder, C. Uhlir, M. Unterwurzacher 2014: Engineering geological properties of Leitha Limestone from historical quarries in Burgenland and Styria, Austria. - Engineering Geology, 176, pp. 66-78. 
Buyuksagis, I.S., R.M. Goktan 2007: The effect of Schmidt hammer type on uniaxial compressive strength prediction of rock. - International Journal of Rock Mechanics and Mining Sciences, 44, pp. 299-307.

Callaway, P., M. Gilbert, C.C. Smith 2012: Influence of backfill on the capacity of masonry arch brides. - Bridge Engineering, 165 (BE3), pp. 147-158.

Cavicchi, A., L. Gambarotta 2006: Two-dimensional finite element upper bound limit analysis of masonry bridges. - Computers and Structures, 84, pp. 2316-2328.

Fitzner, B., K. Heinrichs, R. Kownatzki 1995: Weathering forms-classification and mapping. - In: Denkmalpflege und Naturwissenschaft, Natursteinkonservierung I. Ernst and Sohn, Berlin, pp. 41-88.

Gáll, I. 1970: Régi magyar hidak (Old Hungarian bridges). - Müszaki Kiadó, Budapest, pp. 3-46. (in Hungarian)

Gálos, M., B. Vásárhelyi 2005: Közúti boltozott kőhidaink (Our stone masonry road-bridges). - Díszítő Építő Mű Terméskő, VII/2, pp. 21-25. (in Hungarian)

Gilbert, M., C. Melbourne 1994: Rigid-block analysis of masonry structures. - The Structural Engineer, $72 / 21$, pp. 356-361.

Giordano, A., E. Mele, A.D. Luca 2002: Modelling of historical masonry structures: comparison of different approaches through a case study. - Engineering Structures, 24, pp. 1057-1069.

Gubányi-Kléber J., B. Vásárhelyi 2004: A héhalmi boltozott kőhíd vizsgálata (Investigation of the stone masonry arch bridge of Héhalom). - Mélyépítés, 1, pp. 16-20. (in Hungarian)

Heyman, J. 1995: The Stone Skeleton: Structural Engineering of Masonry Architecture. - Cambridge University Press, Cambridge, $159 \mathrm{p}$.

ICOMOS 2008: Illustrated Glossary on Stone Deterioration Patterns. - ICOMOS-ISCS, Champigny/ Marne, $86 \mathrm{p}$.

ISRM 1978: Suggested methods for determining hardness and abrasiveness of rocks. - Int. J. Rock Mech. Min. Sci., Geomech. Abstr., 15, pp. 89-97.

Janvier-Badosa, S., K. Beck, X. Brunetaud, M. Al-Mukhtar 2014: The occurrence of gypsum in the scaling of stones at the Castle of Chambord (France). - Environmental Earth Sciences, 71/11, pp. 4751-4759.

Kahraman, S. 2001: Evaluation of simple methods for assessing the uniaxial compressive strength of rock. - Int. J. Rock Mech. Min. Sci., 38, pp. 981-994.

Magyar Útügyi Társaság 2006: Útügyi Müszaki Előírás 813/2005 (Technical Standard of Highway Engineering 813/2005). - Magyar Útügyi Társaság, pp. 22-29, 61-108. (in Hungarian)

Martínez-Martínez, J., D. Benavente, M. Gomez-Heras, L. Marco-Castaño, M.Á. García-del-Cura 2013: Non-linear decay of building stones during freeze-thaw weathering processes. - Construction and Building Materials, 38, pp. 443-454.

MSZ 1991:1960. Természetes építőkövek vizsgálati módszerei (Testing Methods of Natural Dimension Stones). - MSZ EN 12371:2002. (in Hungarian)

Orbán, Z. 2006: Condition assessment and rehabilitation of masonry arch railway bridges. - Concrete Structures, 7, pp. 22-30.

Přikryl R. 2007: Understanding the Earth scientist's role in the pre-restoration research of monuments: an overview. - In: Přikryl R., B.J. Smith (Eds): Building Stone Decay: From Diagnosis to Conservation. Geological Society, London, Special Publications, 271, pp. 9-21.

Přikryl, R., A. Št’astná 2010: Contribution of clayey-calcareous silicite to the mechanical properties of structural mortared rubble masonry of the medieval Charles Bridge in Prague (Czech Republic). Engineering Geology, 115, pp. 257-267.

Přikryl, R., J. Svobodová, P. Siegel, M. Chvátal, M. Novotná, R.A. Sanchez, M. Mézlová, K. Mysková, J. Faltus, J. Korecky 2002: Weathering of limestone cladding above the waterproofing layer: salt action due to previous restoration of Colonade (Valtice-Lednice area, Czech Republic). - In: Přikryl, R., H. Viles (Eds): Understanding and Managing Stone Decay. Carolinum Press, Prague, pp. 209-221. 
Přikryl R., Z. Weishauptová, M. Novotná, J. Přikrylová, Št’astná A. 2010: Physical and mechanical properties of the repaired sandstone ashlars in the facing masonry of the Charles Bridge in Prague (Czech Republic) and an analytical study for the causes of its rapid decay. - Environmental Earth Sciences, 63, pp. 1623-1639.

Schafarzik, F. 1904: A magyar szent korona országainak területén létező kőbányák (Stone Quarries in Historical Hungary). - Franklin Társulat Könyvnyomdája, Budapest. (in Hungarian)

Smith, B.J., A.V. Turkington, P.A. Warke, P.A.M. Basheer, J.J. McAlister, J. Menleely, J.M. Curran 2002: Modelling rapid retreat of building sandstones. A case study from a polluted maritime environment. - In: Siegesmund, S., T.S. Weiss, A. Vollbrecht (Eds): Natural Stones, Weathering Phenomena, Conservation Strategies and Case Studies. Geological Society Special Publications, 205, pp. 339-354.

Turkington, A.V., T.R. Paradise 2005: Sandstone weathering: a century of research and innovation. Geomorphology, 67/1-2, pp. 229-253.

Török, Á. 2002: Oolitic limestone in a polluted atmospheric environment in Budapest: weathering phenomena and alterations in physical properties. - Geological Society, London, Special Publications, 205/1, pp. 363-379.

Török, Á. 2003: Surface strength and mineralogy of weathering crusts on limestone buildings in Budapest. - Building and Environment, 38, pp. 1185-1192.

Török Á. 2007: Morphology and detachment mechanism of weathering crusts of porous limestone in the urban environment of Budapest. - Central European Geology, 50/3, pp. 225-240.

Török, Á., N. Rozgonyi, R. Přrikryl, J. Přikrylová 2004: Leithakalk: the ornamental and building stone of Central Europe, an overview. - In: Přikryl, R. (Ed.), Dimension Stone. Balkema, Rotterdam, pp. 89-93.

Török, Á., T. Licha, K. Simon, S. Siegesmund 2011: Urban and rural limestone weathering; the contribution of dust to black crust formation. - Environmental Earth Sciences, 63, pp. 675-693.

Vásárhelyi, B. 2005: Statistical analysis of the influence of water content on the strength of Miocene limestone. - Rock Mechanics and Rock Engineering, 38/1, pp. 69-76.

Warke, P., J. McKinley, J.B. Smith 2006: Variable weathering response in sandstone: factors controlling decay sequences. - Earth Surface Processes and Landforms, 31/6, pp. 715-735.

Yasar, E., Y. Erdogan 2004: Estimation of rock physiomechanical properties using hardness methods. Engineering Geology, 71, pp. 281-288.

Yershov, E.D. 2004: General Geocryology. - Cambridge University Press, Cambridge, 280 p.

Yilmaz, I., H. Sendir 2002: Correlation of Schmidt hardness with unconfined compressive strength and Young's modulus in gypsum from Sivas (Turkey). - Engineering Geology, 66, pp. 211-219.

Yu, S., C.T. Oguchi 2010: Role of pore size distribution in salt uptake, damage, and predicting salt susceptibility of eight types of Japanese building stones. - Engineering Geology, 115, pp. 226-236.

Zhang, L. 2005: Engineering properties of rocks. - Elsevier Geo-Engineering Book Series, 4, pp. $178-181$. 